\title{
Local Government Policies in Handling Domestic Violence (KDRT) During Pandemic COVID-19
}

\author{
Didin Muhafidin \\ Universitas Padjajaran Bandung, Indonesia \\ didin_muhafidin@yahoo.com
}

\begin{abstract}
Corona Virus Disease 2019 or better known as COVID-19, has hit all countries in the world. It can be said that this pandemic is a human tragedy since a lot of people suffer and are seriously ill. The global economy and social institutions are struggling, which adds to totalitarian and oppressive regimes in many nations. In the household sector, COVID-19 has caused vulnerability to family resilience, where the pandemic of a family head has lost his job and income, which impacts the family economy. This will cause various further impacts, such as disharmony, leading to Domestic Violence (KDRT). Therefore, the government needs to make a policy breakthrough in dealing with Domestic Violence (KDRT). Therefore this study aims to discuss government policies, especially local governments, in handling domestic violence due to the COVID-19 pandemic. This study uses a qualitative approach with descriptive methods to provide an overview of the object studied. The results showed that domestic violence increased along with the development of the COVID-19 pandemic. Law No. 23 of 2004 concerning the elimination of domestic violence is not capable of being the only way to deal with these acts of domestic violence. This is due to the implementation that is not running optimally because several regions have high patriarchal culture and have regional policies that contradict the law. This research also encourages local governments to make a policy that involves third parties such as NGOs and organizations dealing with discrimination against women and children. This policy can be more pro-domestic violence victims while being monitored with protocols that apply during the COVID -19 pandemic of this.
\end{abstract}

Keywords

pandemic, COVD-19, family resilience, domestic vidence (KDRI); pdicy

\section{Introduction}

The COVID-19 pandemic that occurred throughout 2020 until now can be a disaster of a non-natural nature (DeWit et al., 2020; Izumi et al., 2020; Israhadi, 2020). This virus is a new disease with a fast transmission rate and a high mortality rate worldwide. Until now, the right drug cannot treat this disease (Roser et al., 2020; Kupferschmidt \& Cohen, 2020; Sanders et al., 2020). Only a vaccine has only been discovered until now, and this has not been proven to prevent a person from contracting this disease. It is estimated that almost all nations are affected by the virus outbreak.

The COVID-19 virus was first reported to have originated in December 2019 from the Chinese town of Wuhan. After further research was carried out by the World Health Organization (WHO), on January 31, 2020, coronavirus was declared a health emergency event worldwide and has become a concern. All countries in the world (Zhu et al., 2020; Adhikari et al., 2020). 2 months after this determination, on March 11, 2020, the virus disease was declared a pandemic. As of January 9, 2021, the number of COVID-19 sufferers has reached $90.833,894$ people, with a death toll of 1,942,974 people worldwide. 
It is unknown when this pandemic will end; even some experts predict that the virus will never completely disappear.

The effect of the virus pandemic is devastating for the entire world community. Not many people thought this pandemic would become a multidimensional crisis (Basundoro \& Sulaiman, 2020; Iping, 2020). Problems that were initially only problems in the health sector eventually expanded to various fields such as education, politics, and economics (Kusno, 2020; Mujani 2020). Millions of people around the world have been affected both directly and indirectly by this pandemic. In the health sector, we can see how as a result of this pandemic, hospitals and health workers are very overwhelmed in dealing with patients suffering from COVID-19, who are increasing day by day and even tend to have uncontrolled growth (Krisnawati et al., 2020). Many hospitals can no longer accommodate people with COVID-19, so many of them are forced to refuse so that many authorities worldwide make hotels or public facility buildings an emergency hospital (Solahudin et al., 2020). The health worker crisis also occurs because seeing the increasing number of COVID-19 patients is not balanced with existing health workers. The existing health workers are very overwhelmed, and sometimes some have sacrificed themselves to be exposed to the virus itself. In education, the impact of the pandemic is also felt. Many schools are closing schools and dismissing their students and learning with an online system or distance learning using information technology (Kurniasari et al., 2020; Widiyono, 2020). This type of education is felt to be less able to make students get maximum results in the learning process (Putria et al., 2020). This is also risky for future generations' advancement and can lead to the lost generation. In the political sector, COVID-19 also has a significant impact. Many government agendas and programs cannot be implemented because all attention, energy, and funds will handle COVID-19 and its consequences (Kurniawansyah et al., 2020). The prohibition of activities resulting in a crowd has caused the government's political plan, such as general elections, not to run well as expected. The Coronavirus outbreak also had a tremendous impact on the economy. Many factories have reduced and even closed their factories due to a lack of demand, so that many of them have laid off their employees and even dismissed their employees (Mardiyah \& Nurwati, 2020). Many traders close their businesses because there are no people who buy their wares due to restrictions or restrictions on activities so that the economic cycle is choked up (Sino, 2020).

The virus outbreak has a significant effect on family resilience (Walsh, 2020). The existence of restrictions on activities results in family members only being able to do exercises at home to not interact with neighbors or the surrounding environment, which results in increased stress levels among family members (Lee et al., 2020). Not to mention the economic impact such as reduced or even loss of family income due to layoffs or bankruptcy of businesses that significantly affect the level of stress on family members, which can affect family resilience, leading to domestic violence (Clemens \& Veuger, 2020). Family Resilience is a combination of functional competence and positive behavior of each individual in a family and each family as a whole (Patterson, 2002). Practical competence and positive action are needed to deal with adverse environmental pressures, such as extraordinary life events. Besides, it also determines the family's capacity to survive and rebuild while preserving dignity and stability as a family as a whole. (Walsh, 1996).

A significant amount of domestic abuse has arisen from the instability of family resilience in the face of the virus outbreak (Suteja \& Marjuki, 2020). Several factors trigger the emergence of domestic violence, including changes in workloads and patterns of care at home during a pandemic; a decline in the family economy which results in an imbalance between expenditure and income, increasing the stress level for each family; having children 
studying at home has added to the burden on homemakers, thus adding to the pressure (Radhitya et al., 2020). Based on the Covid19.go.id website, there has been a drastic increase in domestic violence (KDRT). Lembaga Bantuan Hukum Asosiasi Perempuan Indonesia untuk Keadilan (LBH APIK) noted that in 2019 an average of 66 cases of domestic violence reported cases per month reached his party. However, during the pandemic, The number of domestic violence incidents rose to 97 points. In other countries, such as Singapore, there is also a similar experience where there has been an increase in domestic violence reports by 33 percent.

Given the high prevalence of domestic abuse during the virus outbreak, where the bulk of casualties were female and children, the government should pay heed to this. The government must be able to offer sufficient protection and care for victims of domestic abuse. For this cause, the government needs to follow a strategy to resolve domestic violence (KDRT) during the COVID-19 pandemic so that victims of domestic violence, particularly women and children, can be better treated. The writers are also engaged in conducting studies to evaluate government strategies to counter domestic violence (KDRT) during the COVID-19 pandemic. It is hoped that this report would include recommendations about how to address the rising prevalence of domestic abuse during the COVID-19 pandemic.

\section{Research Methods}

Research on government policies in handling domestic violence (KDRT) uses a qualitative approach. Qualitative techniques, as the name suggests, are methods that do not require calculations or numbers. Since natural science has had considerable success with quantitative approaches, qualitative methods are often thought to be less scientific. That was an error, of course. For decades, relational systems have been used in philosophy, economics, and history (Anggito \& Setiawan, 2018). Qualitative assessment methods are designed in a manner that aims to reveal the behavior and perceptions of the focus audience concerning the subject. Various qualitative interviewing methods, such as indepth interviews, focus groups, ethnographic research, subject analysis, and case studies, are commonly used (Nugrahani \& Hum, 2014).

In analyzing the object under study, the author uses descriptive qualitative methods. Qualitative descriptive research aims to summarize systematically, regularly, those activities encountered by individuals or groups of individuals (Soendari, 2014). There are no such qualitative design definitions for other scholars. Unfortunately, this has caused other researchers, particularly newbies, to feel that they can protect their research methodology by giving it "epistemological credibility."

Qualitative descriptive analysis is the least "theoretical" of all qualitative research methods. Furthermore, qualitative descriptive experiments are the least burdened, relative to other qualitative methods, by pre-existing theoretical or conceptual commitments. For example, phenomenology, fundamental theory, and ethnography are focused on unique philosophical structures that have originated from a particular discipline's traditions. In contrast, qualitative descriptive experiments aim to draw on naturalistic science, which carries forth the determination to analyze something in its natural state as much as possible in the sense of the research arena. There were no pre-selected research factors, no manipulating of variables, and no previous adherence to a particular scientific interpretation of the aim phenomena. Qualitative descriptive research can have a wasteful theoretical base since they use constant comparative comparison when analyzing results. However, a qualitative descriptive analysis is not a ground-breaking hypothesis since it does not generate a theory from the resulting consequences. 


\section{Results and Discussion}

\subsection{Corona Virus Disease 2019 (COVID-19)}

Coronavirus is a disease caused by the coronavirus and causes the main symptoms of respiratory problems. This disease is in the spotlight because of its appearance at the end of 2019 for the first time in Wuhan, China (Zhu et al., 2020). For the first time, the location of its appearance made the coronavirus, also known as the Wuhan virus. Apart from China, the coronavirus has also spread rapidly to various other countries, including Japan, Thailand, Japan, South Korea, and even the United States.

The cause of coronavirus is a single-stranded RNA virus that comes from the Coronaviridae group (Egloff et al., 2004) — named coronavirus because of its crownshaped surface (crown/corona) (Prastyowati, 2020). Another virus that belongs to a similar group is the virus that caused Middle East Respiratory Syndrome (MERS-CoV) and Severe Acute Respiratory Syndrome (SARS-CoV) several years ago. However, the coronavirus is a novel virus that has never been detected in humans before. Therefore, this virus is referred to as the 2019 Novel Coronavirus or 2019-nCoV (Isbaniah, 2020).

Coronaviruses are commonly found in wildlife, such as camels, snakes, poultry, cats, and bats. People may contract the virus if there is a history of contact with the animal. The increase in the number of instances in Wuhan, China, shows that the coronary virus can be spread from person to person. Viruses can be transmitted through droplets, which are water particles that are very small and usually come out when coughing or sneezing. If the droplets are inhaled or hit the lining of the eye's cornea, a person is at risk for contracting this disease. Although everyone can be infected with the coronavirus, those who are elderly, have chronic conditions, and have low immunity are more susceptible to this infection and its complications (Nasution, Wijaya, 2020).

Coronavirus symptoms range from the common cold to severe respiratory problems like pneumonia. Symptoms of Corona that are commonly experienced by those who experience coronavirus infection are (Safitri, 2020):

- High fever with chills

- Dry cough

- Colds

- Runny nose and sneezing

- Sore throat

- Hard to breathe

Symptoms of coronary artery virus can worsen rapidly and cause respiratory failure and death. The Centers for Disease Control and Prevention (CDC) signs of the 2019-nCoV virus infection can appear from two days to 14 days after exposure to the virus.

Coronavirus infection is generally known through symptoms and physical examination that patients complain of. After that, the doctor will perform several supporting studies to help make a diagnosis. These supporting examinations include complete blood count, blood clotting, kidney and liver function tests, and virological studies. Besides, specimens from the patient's nose and pharynx (throat) will be taken using a swabbing technique. Likewise, sputum preparations and, if necessary, bronchial fluid (smaller respiratory tract). This examination can determine whether a virus or other cause causes the patient's illness.

Meanwhile, the patient's blood plasma will also be examined to find the corona virus's RNA. For radiological examinations, chest $\mathrm{x}$-rays and chest $\mathrm{CT}$ scans can be performed. Most patients will show a picture of turbidity in both lungs (Huang et al., 2020). 
Patients infected with the coronavirus may experience respiratory symptoms such as severe pneumonia, such as high fever, and shortness of breath. Complications such as respiratory failure, acute heart failure, and secondary infections due to other germs can occur if the condition is not treated promptly or if the disease worsens very quickly (Wu et al., 2020).

To date, no anti-viral therapy has been proven to be effective against 2019-novel coronavirus infection. Several anti-viruses that have successfully dealt with previous MERS-CoV and SARS-CoV infections have not shown satisfactory results in overcoming this new coronavirus infection. Patients infected with the coronavirus will receive supportive therapy to reduce symptoms. For example, antipyretics to lower body temperature and fluids to prevent dehydration, and oxygen therapy in patients who experience shortness of breath. In severe conditions, breath assistance through a ventilator machine can be given to patients to support other vital organs (Huang et al., 2020).

Although coronavirus disease symptoms resemble other respiratory diseases such as pneumonia or influenza, so far, no vaccine can prevent transmission of the coronavirus disease. Giving a pneumonia vaccine or influenza vaccine cannot protect against the spread of coronavirus infection (Wu et al., 2020).

\subsection{Domestic Violence}

Domestic abuse (abbreviated as KDRT) is violence perpetrated in the home by both the spouse. Law No. 23 of 2004 concerning the elimination of domestic violence article 1 paragraph 1 explains that domestic violence is any act against someone, especially women, which results in physical, sexual, psychological, and/or neglect of the household, including threats to commit actions, coercion, or illegal deprivation of liberty within the scope of the family. The bulk of domestic abuse victims are women (wives), and the offenders are husbands, but some victims do not, or individuals who are subordinates in the family (Afdal, 2015). Perpetrators of domestic violence victims are related by blood, marriage, breastfeeding, caregiving, guardianship with husbands and children, and even household helpers living in this house. Ironically, domestic violence incidents are mostly covered by women because they are related to socioeconomic traditions, religions, and justice processes that have not yet been understood. In comparison, the state and society's protection aims to provide a sense of security to victims and take action against the perpetrators (Afdal, 2015).

Women and girls are the majority of victims of domestic abuse. Russell \& Clarkson (1992) said that the patriarchal power that exists because of society's culture and values makes women victims of domestic violence. In Indonesia, some communities still adhere to patriarchal power in carrying out married life. Men in life have been formed to have "power" to determine the direction in society (Aisyah, 2013). The relationship between men and women in Indonesia is seen as socio-culturally based on several reasons: (a) Men are physically stronger than women. Likely, the level of aggressiveness of men is also high when viewed from a biological basis. Men in social life often train to use physicality, weapons, and intimidation since childhood; (b) Society has a tradition of male dominance over women and is more tolerant of men using force. We can see this tradition through the existence of films, pornography, music, and other media; (c) there is an economic reality in which women must accept abuse from the people on whom their lives depend. ; (d) some men commit violence and some women other than that some men do not commit violence and some women are also not targets in violence; (e) the conclusion is that there is a difference in strength and power in women and men, which in this case is perceived as a right and ability to control each other (Radhitya et al., 2020). 
Women have the nature of nature, where this trait has a reciprocal relationship with nature due to productive and creative features (Gardner, 2006), while men are synonymous with exploiting nature. Men and women have different roles from each other. This difference is due to biological differences. The difference in parts can be seen from the nurture theory, where differences result from cultural and societal constructs that place men ahead of women. In society, women are seen as those who do not have physical strength, are weak, emotional, and only have the right to do fine jobs, including homework, caring for children, etc. In this way, domestic violence emerges because of the assumptions of the community.

\subsection{Local Government Policies for Handling Domestic Violence during the COVID-19 Pandemic}

As stated earlier, the number of cases of domestic abuse rose dramatically during the COVID-19 pandemic. A policy of limiting activities outside the home or known as PSBB makes individuals isolated in a limited environment. This will cause the individual to experience depression, anxiety, and mental health, which can lead to domestic violence (KDRT). ). Besides, the COVID-19 pandemic has also threatened the family's economic condition. This is due to the mass layoffs of employees caused by factories that reduce production volume and even stop production due to reduced demand. The releases will certainly trigger stress and anxiety because they think about the cost of living. So fathers who make a living can take it out on their wives and children in the form of violence.

The Central Government has made a policy that regulates domestic violence. This policy is stipulated in Law No. 23 of 2004 concerning the Elimination of Domestic Violence. Law No. 23 of 2004 is a public policy that aims to eradicate domestic violence. Although this law is full of values that are influenced by the understanding of human rights and gender equality, which essentially enforces the equality of men and women, in its enactment in Indonesia, it could not reduce the degree of domestic abuse in that nation.

There are two approaches to tackling crimes (criminal policy) in Indonesia, such as domestic violence. First, the penal process (criminal law) is more repressive. Second, the non-penal approach (not criminal law), and this approach are more preventive. In Indonesia, victims' prevention of domestic violence using criminal law can be pursued by submitting reports to the Women and Children Service Unit (UPPA) in several police agencies under the criminal investigation unit (Satreskrim).

The criminal sanctions in violation of Law No.23 of 2004 concerning PKDRT are regulated in Chapter VIII starting from article 44 to article 53 of the Criminal Code. Mainly for domestic violence in the sexual sector, a minimum of 5 years in prison and a maximum of 15 years in jail or 20 years in prison or a fine of between 12 million and 300 million rupiahs or between 25 million and 500 million rupiahs applies (Read: article 47 and 48 of the PKDRT Law). And it should also be noted that in general Law No.23 of 2004 concerning KDRT is aimed at a husband and can be addressed to a wife who has committed violence against her husband, children, family, or assistants who live in one the household.

The approach to tackling domestic violence through a process outside the criminal law (Non-Penal Policy) is carried out by the government of cooperation of the ministry of women's empowerment and child protection. In the era of decentralization, institutions' names between regions are undoubtedly different from one another, but in operation, these institutions emphasize domestic violence prevention. So non-penal can be defined as any non-juridical effort to tackle the onset of crime. And these non-penal efforts have a very strategic position because they focus more on prevention. 
The question that arises then is why, despite the penal and non-penal approaches, domestic violence is still ongoing, and even from year to year, it has increased. From the fact that there has been an increase in domestic violence actions, the government must evaluate the KDRT prevention program. Because in the field, the lack of participation of women and the limited number of non-governmental organizations (NGOs) in guarding the elimination of domestic violence are some of the reasons why domestic violence continues to occur. In this case, the government must realize that the hand of power owned through these two channels is limited, and it needs public participation to participate.

In several regions where the values of a patriarchal culture are still high, domestic violence is very concerning. So that Law no. 23 of 2004 is less effective. Not infrequently, in the implementation of UUPKDRT, there are contradictions in official policies in several regions, so that efforts to overcome domestic violence stagnate and even experience a setback. Several examples released by Komnas Perempuan through its 2014 annual notes stated that some areas were less responsive to domestic violence. Some of them are cases of criminalization of domestic violence victims in the Watampone district court; victim $\mathrm{E}$ (17) is even charged with neglecting her household because she is considered to have left home for school. Even in 2014, the regent of East Lombok regulation number 26 regarding the implementation of regional regulation number 3 of 2013 concerning other legal local revenue (regarding polygamy permits). Besides, there are qonuns on jinayat laws and basic qonuns of Islamic law in Aceh that regulate the issue of adultery, rape and the application of caning as a way of punishment, even strengthening immunity for perpetrators, as well as new discriminatory policies (out of a total of 365 discriminatory policies) throughout Indonesia.

In this regard, the regional government, in this case, needs to make a policy breakthrough that should be able to be more impartial and protect victims of domestic violence (KDRT), which are mainly women and children. Moreover, this policy is more urgent during the virus outbreak, where the number of domestic abuse increases.

Local governments can make several policies to take a role in handling Domestic Violence, such as creating An organized web of programs for women and children who are victims of domestic abuse. This policy can involve third parties, such as organizations or NGOs that are genuinely concerned about domestic violence. The collaboration between the local government and institutions related to domestic violence will create a very good social network that is complementary to each other, which can provide full service to domestic violence victims.

As has been developing in Indonesian culture, often domestic violence cases in which the primary victims are women and children are always covered up. There is a view that disclosing what happens in the household is taboo, disgraceful, and private and should not be interfered with by outsiders even though the household problem is a form of violence. This stigma makes victims of domestic violence often confused about whether to report and where to report if they want to. The creation of a Comprehensive Care Structure for Women and Children Victims of Domestic Abuse is also likely to shift the attitudes of domestic violence victims so that they can complain and know where to report. This integrated service system will provide comprehensive protection and professional assistance from credible institutions that cooperate with the government, which is indeed concerned about domestic violence.

There are several reasons for the appointment of a third party in the handling of domestic violence by the local government, especially amid an increase in domestic violence cases during this pandemic, namely: First, this policy can answer various problems of domestic violence because of the existence of a particular institution or 
organization appointed by the government in handling domestic violence acts. With this organization, which becomes a forum for domestic violence victims to report violence, it is hoped that the number of reports on domestic violence can increase so that they get help and assistance as soon as possible. Second, by appointing the right organization or institution to handle acts of violence, local government policies are right on target. The organizational commitment aimed at providing services and assistance to domestic abuse victims is very influential for the success of this policy. Third, by involving nongovernmental organizations related to domestic violence, this policy indirectly also consists of the community. With the community's involvement, it is hoped that in the future, the community will be more aware of the importance of reporting acts of violence in the household so that, in the end, It could boost the quality of life of the society itself.

Especially during the COVID-19 pandemic, a protocol is needed to deal with domestic violence victims so that organizations or institutions designated to serve can provide full service while still implementing the existing protocol. This protocol was adapted from the Guidelines for Handling Gender-Based Violence compiled by the Jakarta Center for Integrated Services for Women and Children Empowerment (P2TP2A), Pulih Foundation, and Joint Service Provider Institutions of the Ministry of PPPA and UNFPA in 2020. The available protocols start from the complaint protocol, providing assistance services; referral to health services; referral to a safe house or shelter; psychosocial services; legal consulting services; to legal process assistance. This protocol can be applied in handling domestic violence cases because domestic violence is a form of violence against women. The available protocols include:

1. Protocol for complaints of cases of violence against women during the Covid-19 pandemic

2. Protocol for providing assistance services for violence against women during the Covid19 pandemic

3. Referral protocol to health services on violence against women during the Covid-19 pandemic

4. Referral protocol to safe houses or shelters for violence against women during the Covid-19 pandemic

5. Protocol for psychosocial services for violence against women during the Covid-19 pandemic

6. A protocol for legal counseling services on violence against women during the Covid19 pandemic

7. Protocol for legal process assistance on violence against women during the Covid-19 pandemic

8. A protocol for escaping violence against women during the Covid-19 pandemic

With the existence of these protocols, it is hoped that they can become a guide that can be replicated by service institutions in each region by adjusting the content and coverage to the regional context, regional policies, and regional resources to provide comprehensive services by prioritizing the safety of service agency officers and reporter. In general, the purpose of this protocol is to "provide a Protocol for Handling Cases of Violence Against Women who are victims following handling procedures during the COVID-19 pandemic." (Syahrin et al., 2020). 


\section{Conclusion}

The virus outbreak ravaged all facets of life around the world. The Coronavirus outbreak has turned into a multidimensional crisis that has significantly impacted all sectors ranging from health, education, social, politics, and economy. Many problems have arisen with this pandemic, one of which is the increasing incidence of domestic abuse (KDRT). The Origin of domestic abuse is due to this limitation, which is due to the government's restriction on activity, which causes individuals to be isolated in a narrow community, which of course will increase stress, anxiety, and mental disorders, which in turn can trigger violence in the home. Stairs. The economic factor where the mass layoffs occurred everywhere caused stress to estimate daily living costs could also trigger acts of violence.

Given the rise in domestic abuse during the COVID-19 pandemic, local governments must provide policies in dealing with victims of domestic abuse. This is necessary because Law No. 23 of 2004 on Domestic Violence alone is not sufficient to become a foothold in handling domestic violence. Each region has its characteristics and several areas with regional policies that contradict this law. One of the procedures that can be implemented is to create an integrated service system for women and children victims of domestic violence. This system involves a third party, namely non-governmental organizations or organizations concerned about giving attention to domestic violence victims. This policy aims to involve third parties to make this policy more targeted because this institution knows and has more experience in dealing with domestic violence. Besides that, involving non-governmental organizations means that local governments also apply the community to handle domestic violence so that the government can understand domestic violence.

\section{References}

Adhikari, S. P., Meng, S., Wu, Y. J., Mao, Y. P., Ye, R. X., Wang, Q. Z., ... \& Zhou, H. (2020). Epidemiology, Causes, Clinical Manifestation and Diagnosis, Prevention and Control of Coronavirus Disease (COVID-19) During The Early Outbreak Period: A Scoping Review. Infectious Diseases of Poverty, 9(1), 1-12

Afdal, A. (2015). Pemanfaatan Konseling Keluarga Eksperensial untuk Penyelesaian Kasus Kekerasan dalam Rumah Tangga. Jurnal EDUCATIO: Jurnal Pendidikan Indonesia, 1(1).

Aisyah, N. (2013). Relasi Gender dalam Institusi Keluarga (Pandangan Teori Sosial dan Feminis). Jurnal Muwazah, 5(2), 203-224.

Anggito, A., \& Setiawan, J. (2018). Metodologi Penelitian kualitatif. CV Jejak (Jejak Publisher).

Arthi, V., \& Parman, J. (2020). Disease, Downturns, and Wellbeing: Economic History and The Long-Run Impacts Of COVID-19. Explorations in Economic History, 79, 101381.

Basundoro, A. F., \& Sulaeman, F. H. (2020). Meninjau Pengembangan Food Estate Sebagai Strategi Ketahanan Nasional Pada Era Pandemi Covid-19. Jurnal Kajian Lemhannas RI, 8(2).

Clemens, J., \& Veuger, S. (2020). Implications of The Covid-19 Pandemic for State Government Tax Revenues (No. w27426). National Bureau of Economic Research.

DeWit, A., Shaw, R., \& Djalante, R. (2020). An Integrated Approach to Sustainable Development, National Resilience, and COVID-19 Responses: The Case of Japan. International Journal of Disaster Risk Reduction. 
Egloff, M. P., Ferron, F., Campanacci, V., Longhi, S., Rancurel, C., Dutartre, H., ... \& Canard, B. (2004). The Severe Acute Respiratory Syndrome-Coronavirus Replicative Protein Nsp9 is A Single-Stranded RNA-Binding Subunit Unique in The RNA Virus World. Proceedings of the National Academy of Sciences, 101(11), 3792-3796.

Gardner, C. V. (2006). Historical Dictionary of Feminist Philosophy (No. 64). Lanham, MD: Scarecrow Press.

Huang, Z., Zhao, S., Li, Z., Chen, W., Zhao, L., Deng, L., \& Song, B. (2020). The Battle Against Coronavirus Disease 2019 (COVID-19): Emergency Management and Infection Control in A Radiology Department. Journal of the American college of radiology.

Iping, B. (2020). Perlindungan Sosial Melalui Kebijakan Program Bantuan Langsung Tunai (BLT) di Era Pandemi Covid-19: Tinjauan perspektif ekonomi dan sosial. Jurnal Manajemen Pendidikan Dan Ilmu Sosial, 1(2), 516-526.

Isbaniah, F. (2020). Pedoman Pencegahan dan Pengendalian Corona Virus Disease (Covid19). Yogyakarta: UGM.

Israhadi, E. (2020). The Social Impact of Force Majeure and The consequences of the Determination of the Covid 19 Disaster Status on Learning the Manpower Law. Journal of Social Studies Education Research, 11(4), 28-51.

Izumi, T., Sukhwani, V., Surjan, A., \& Shaw, R. (2020). Managing and Responding to Pandemics in Higher Educational Institutions: Initial Learning from COVID-19. International Journal of Disaster Resilience in the Built Environment.

Krisnawati, M., Pitaloka, J., \& Jullyandri, A. (2020). Resiko Dan Upaya Pencegahan Pandemi Covid-19 Bagi Masyarakat RSPAU dr. S. Hardjolukito. ABDIMAS Madani, 2(2), 45-50.

Kupferschmidt, K., \& Cohen, J. (2020). Race to Find COVID-19 Treatments Accelerates. New York: AAAS

Kurniasari, A., Pribowo, F. S. P., \& Putra, D. A. (2020). Analisis Efektivitas Pelaksanaan Belajar Dari Rumah (Bdr) Selama Pandemi Covid-19. Jurnal Review Pendidikan Dasar: Jurnal Kajian Pendidikan Dan Hasil Penelitian, 6(3), 246-253.

Kurniawansyah, H., Amrullah, A., Salahuddin, M., Muslim, M., \& Nurhidayati, S. (2020). Konsep Kebijakan Strategis Dalam Menangani Eksternalitas Ekonomi dari COVID19 Pada Masyarakat Rentan di Indonesia. Indonesian Journal of Social Sciences and Humanities, 1(2), 130-139.

Kusno, F. (2020). Krisis Politik Ekonomi Global Dampak Pandemi Covid-19. Anterior Jurnal, 19(2), 94-102.

Law number 23 of 2004 concerning The Elimination of Domestic Violence.

Lee, K., Jeong, G. C., \& Yim, J. (2020). Consideration of the Psychological and Mental Health of the Elderly during COVID-19: A Theoretical Review. International Journal of Environmental Research and Public Health, 17(21), 8098.

Mardiyah, R. A., \& Nurwati, R. N. (2020). Dampak Pandemi Covid-19 Terhadap Peningkatan Angka Pengangguran Di Indonesia. Universitas Padjajaran, Bandung

Mujani, S. (2020). Asesmen Publik Atas Kinerja Pemerintah Indonesia Menangani Wabah Covid-19: Sebuah Penjelasan Ekonomi Politik. Jurnal Penelitian Politik, 17(2), 159178.

Nasution, N. H., \& Wijaya, W. (2020). Manajemen Masjid Pada Masa Pandemi Covid 19. Yonetim: Jurnal Manajemen Dakwah, 3(01), 84-104.

Nugrahani, F., \& Hum, M. (2014). Metode Penelitian Kualitatif. Solo: Cakra Books.

Patterson, J. M. (2002). Understanding Family Resilience. Journal of Clinical Psychology, 58(3), 233-246. 
Prastyowati, A. (2020). Mengenal Karakteristik Virus SARS-CoV-2 Penyebab Penyakit COVID-19 Sebagai Dasar Upaya Untuk Pengembangan Obat Antivirus Dan Vaksin. Biotrends, 11(1), 1-10.

Putria, H., Maula, L. H., \& Uswatun, D. A. (2020). Analisis Proses Pembelajaran Dalam Jaringan (Daring) Masa Pandemi Covid-19 Pada Guru Sekolah Dasar. Jurnal Basicedu, 4(4), 861-870.

Radhitya, T. V., Nurwati, N., \& Irfan, M. (2020). Dampak Pandemi COVID-19 Terhadap Kekerasan dalam Rumah Tangga. Jurnal Kolaborasi Resolusi Konflik, 2(2), 111-119.

Roser, M., Ritchie, H., Ortiz-Ospina, E., \& Hasell, J. (2020). Coronavirus Disease (COVID-19)-Statistics and Research. Our world in data.

Russell, L. M., \& Clarkson, J. S. (Eds.). (1996). Dictionary Of Feminist Theologies. Louisville Kentucky: Westminster John Knox Press.

Safitry, O. (2020). Penanganan Covid-19: Pengalaman RSUI. Depok: Universitas Indonesia Publishing.

Sanders, J. M., Monogue, M. L., Jodlowski, T. Z., \& Cutrell, J. B. (2020). Pharmacologic Treatments for Coronavirus Disease 2019 (COVID-19): A Review. Jama, 323(18), 1824-1836.

Sina, P. G. (2020). Ekonomi Rumah Tangga Di Era Pandemi Covid-19. Journal of Management: Small and Medium Enterprises (SMEs), 12(2), 239-254.

Soendari, T. (2012). Metode Penelitian Deskriptif. Bandung, UPI.

Solahudin, D., Amin, D. E. S., Sumpena, D., \& Hilman, F. A. (2020). Analisis Kepemimpinan Di Indonesia Dalam Kerangka Tanggap-Darurat Covid-19. Writing Scientific Papers of UIN Sunan Gunung Djati Bandung in the Work From Home Period in 2020.

Syahrin, A., Asiah. N., \& Dewi, D. K. (2020). Pengembangan Protokol Perlindungan Hukum Pada Korban KDRT Di Masa Pandemi Covid 19 Dalam Meningkatkan Kualitas Hidup Wanita. ResearchGate.

Walsh, F. (1996). The Concept of Family Resilience: Crisis and Challenge. Family Process, 35(3), 261-281.

Walsh, F. (2020). Loss and Resilience in The Time Of COVID-19: Meaning Making, Hope, And Transcendence. Family Process, 59(3), 898-911.

Widiyono, A. (2020). Efektifitas Perkuliahan Daring (Online) Pada Mahasiswa PGSD Di Saat Pandemi Covid 19. Jurnal Pendidikan, 8(2), 169-177.

Wu, C., Chen, X., Cai, Y., Zhou, X., Xu, S., Huang, H., ... \& Song, Y. (2020). Risk Factors Associated with Acute Respiratory Distress Syndrome and Death in Patients With Coronavirus Disease 2019 Pneumonia In Wuhan, China. JAMA Internal Medicine.

Zhu, N., Zhang, D., Wang, W., Li, X., Yang, B., Song, J., ... \& Niu, P. (2020). A Novel Coronavirus from Patients with Pneumonia In China, 2019. New England Journal of Medicine, 382, 727-733 